\title{
On the Choice and Comparison of Financing Methods of Transnational Enterprises
}

\author{
Liyun Xu
}

Anhui University, Hefei, 230601, China

Keywords: transnational enterprise, financing method, choice, comparison

\begin{abstract}
With the development of economic globalization, transnational enterprises, as an advanced form of enterprise organization, are at the forefront of other enterprises. In particular after China's accession to the WTO, many companies begun to transfer their development to international capital market, and transnational enterprises have improved significantly both in terms of quantity and funds. Therefore, in view of the current analysis of financing methods of transnational enterprises, this paper puts forward some relevant suggestions.
\end{abstract}

\section{Introduction}

Under the current situation, China's transnational enterprises are getting better and better internationally and still in the continuous development to be strong and big. Compared with multinational corporations in other countries, China have lagged far behind them. Therefore, in view of the current problems, in the process of future development, China's transnational corporations should continue to issue stocks abroad, establish related fund investment projects, constantly increase the methods of financing, open overseas capital market to enhance its national popularity in the overseas market, and competitiveness in the overseas capital market.

\section{Analysis of Current Financing Methods in Transnational Enterprises}

Transnational enterprises can finance through bank loans, which are based on a comprehensive analysis of their own, including assets and scale of the company, as well as its future development prospects. Bank loans are examined and approved by the bank. The advantage of bank loans lies in the financing process etc., which is relatively simple and convenient to some extent, at the same time, the risk is relatively small. While, drawback is that they are regulated by the state finance and restricted by the size of banks, but generally speaking, the cost of transnational enterprises' bank loans is higher compared with other financing methods.

As we all know, the issuance of stocks is relatively influenced to a large extent by the policy of the state and are monitored by the China Securities Regulatory Commission. It is a must to get China Securities Regulatory Commission's approval before the issuance of stock. However, compared with the current domestic enterprises in terms of stock financing, transnational enterprises have certain advantages. While cost of stock financing is relatively higher, so from the perspective of investors, the risk of stock financing is also relatively higher. In addition, the time span of stock financing listing is longer, therefore competition is increasingly fierce. All of these stimulate the urgent financing needs of enterprises, therefore, the diversification of investment can reduce the risk of investment to a certain extent. Domestic capital market and foreign capital market are fundamental effective ways to achieve diversification of financing. Because of the existence of transnational enterprises, investors can invest in some states, which is conducive to effectively disperse the risk of financing.

Transnational enterprises finance through the issuance of bonds. Its main advantages are relatively long repayment period, less additional restrictions and relatively low cost of funds. However, the procedure is very complex, the requirements for enterprises are strict, bonds exchange is not active, and risk of issuing is also higher. Besides, the issuance of bonds requires the approval of the China Securities Regulatory Commission. In addition, projects involved in enterprises bonds 
need to be examined and approved by the National Development and Reform Commission, and the guarantee of state-owned enterprises needs the approval of the SASAC [2]. Most investors of bonds issuing are financial institutions related to insurance company and banks etc. The procedure is complex and supervision and management are strict. However, the financing of bonds is high and cost of financing is low. This optimizes the structure of corporate bonds to a certain extent, thus effectively avoiding the dispersion of equity.

If transnational enterprises want to issue short-term financing vouchers and medium-term bills, it is necessary to follow conditions of the Management of Non-financial Bond Financing Tools in the Inter-bank Bond Market and related process [2]. It is one of the main financing methods for transnational enterprises to issue short-term financing bonds and medium-term notes in the inter-bank market. Short term financing is more suitable to meet their needs. Its main financing costs are low and the amount of funds is relatively larger. The issuance of short-term financing vouchers can improve the reputation and popularity of transnational enterprises to a certain extent. However, risk of financing securities is high, besides, short term issue of financing and terms of medium-term notes are strict.

\section{Analysis of Overseas Financing Methods of Transnational Enterprises}

Foreign currency bonds issued by multinational corporations are generally similar to domestic bonds to a certain extent. Enterprises adopt the overseas bond issuing method of "internal guarantee external debt". The issuance of bonds abroad is also a way of financing, not only to help enterprises to quickly finance, but also to improve their reputation abroad, so as to improve their market competitiveness. However, the so-called "internal security external debt" refers to domestic transnational enterprises guaranteeing the branch overseas and providing supply for the issuance of bonds abroad, and then approving foreign debt indicators through the Foreign Exchange Bureau. Foreign debt refers to foreign companies' bonds of overseas branch for effective financing. The advantages of foreign currency bond issuance are that the use of funds is more free than domestic bonds, the choices of currency are more as well as long term bonds and medium and long-term funds can be obtained. To a certain extent, these provide a good economic foundation for company's financing.

In general, foreign financing products are widely called, including external debt internal loan, internal insurance foreign debt, overseas direct loan, internal insurance and other forms of financing. Most financial products are funded by foreign banks, while foreign banks and domestic banks cooperate through the modes of financing guarantee, risk participation and so on. Financial products flow into our territory in the form of foreign debt and through a series of processes, ultimately complete financing. In addition, enterprises without overseas financing channels can seek help from domestic banks, and banks within the territory agree to lend loans to overseas banks in the form of financial guarantee.

The so-called overseas issuance of stock refers to the financing mode of issuing stocks of transnational enterprises in the international capital market which is in line with the issuing conditions of overseas stock to a certain extent. Therefore, when issuing their shares in the overseas capital market, transnational enterprises should fully comply with the relevant rules and regulations to ensure the smooth progress of overseas stock issuance. In addition, the issuance of stock can not only effectively raise a large amount of foreign capital, but also improve companies' reputation and enhance their competitiveness in the international market. This improves the international operation level of multinational corporations to a certain extent.

The so-called overseas investment fund mainly refers to the needs of multinational companies for their development. An investment fund company is set up internationally according to company's plan, or a project organization of a certain fund, raising a large amount of funds to the overseas investors. However, funds raised must meet the principle of earmarked appropriations. For example, in the future development of companies, if they find a suitable project and product related to research and development, this capital can be used. Overseas investment funds are open to the vast majority of foreign investors. However, the financing of overseas investment funds is 
conducive to the rapid financing of multinational companies, the cost of financing is relatively low and raising is easy.

\section{Financing Strategies in Accordance with Financing Methods}

Whether the internal financing structure of transnational enterprises is optimized or rationalized is the most important aspect of international financing. If in the actual development, financial system of transnational enterprises cannot achieve a reasonable normalization, their ratio of debt is relatively high, and the state financing is small, it is difficult to achieve the optimization of financing structure of the current international market. In the current international capital market, China's transnational enterprises should formulate a financing method that accords with national conditions according to the actual situation. Transnational enterprises must insist on low financing cost and maximal profits, so as to effectively reduce liabilities and improve profits. In addition, it is necessary to fully consider related factors affecting financing, especially financing structure factors of enterprises, which to a certain extent, influence their market value. In addition, the effective optimization of their financing structure can reduce the cost of financing and reduce various risks.

In the process of selecting specific financing methods, transnational enterprises should make a comprehensive analysis according to the overall structure of the current world capital market and economic globalization, taking into consideration their concrete actual situation and the future development. Reasonable and scientific choice of financing method can not only reduce the cost of financing, but also greatly reduce risks, thus promoting the maximization of companies' interests. Transnational corporations need to make full use of the financing structure to control cost. In addition, in the actual development process of transnational enterprises, they are expected to pay full attention to widen financing channels, consider their interests in a comprehensive way, and combine the current actual situation so as to improve the comprehensive interests of transnational corporations, but not only rely on any kind of financing method.

Under the current situation, international capital market is changing because our transnational enterprises are in the initial stage of development. Therefore, in the face of changes in national capital market, China's multinational companies should do a good job in coping with relevant countermeasures. In the actual development process, they should give full consideration to every risk factor that will affect financing. For example, it is necessary to take into account risks associated with the cost of repayment due to the change of exchange rate, so transnational enterprises should actively take relevant measures to ensure that the impact of exchange rate fluctuations will be resolved to a certain extent. In a word, these companies must fully grasp relevant influencing factors so as to ensure their safe, orderly and stable development in international market.

Under the current situation, there are some differences between transnational enterprises in other countries and those in China. Since multinational corporations in China have certain political background factors, they are vulnerable to administrative intervention, which seriously causes their disadvantages in the competition of international market. As a result, it is necessary for them to continue to get improvement, actively participate in the competition in overseas capital market, and continue to seek financing ways. In the process of actual financing, transnational enterprises should make an effective way to finance themselves according to the environment of overseas capital market, their own development needs, and their own current situation. In addition, they need to continue to strengthen their international financing, broaden financing channels among international cities, reduce the cost of financing, and further enhance the popularity of multinational companies in international capital market, thus maximizing the benefits.

\section{Conclusion}

To sum up, although China's multinational corporations have made some achievements in the international capital market and quantity, because of the relatively late start, their international influence in overseas capital market is far less than that of other countries' multinational 
corporations. Therefore, in the future development planning, transnational enterprises in China should actively study the advanced management concepts of overseas transnational enterprises, continuously optimize and upgrade them so as to enhance their popularity and enhance the influence and competitiveness in the overseas capital market.

\section{References}

[1] Dong Hang. Analysis of Financing Structure of Multinational Corporations [D]. Capital University of Economics and Business, 2016.

[2] Lei Hao. Analysis of the Choice and Comparison of Financing Methods of MNCs, [J]. Market Modernization Magazine, 2015 (12): 197.

[3] Zhang Jiaming. Research on Financing Structure and Transformation of Foreign Capital Enterprises in China [D]. Soochow University, 2009

[4] Yan Liping. Enlightenment of the Western Multinational Corporations' Capital Structure to the Financing Strategy of China's Multinational Corporations [D]. Shanghai Maritime University, 2007.

[5] Chen Yu. Research on the Financing Structure and Optimization Strategies of China's Multinational Corporations [D]. Guangdong University of Foreign Studies, 2006.

[6] Guo Jiannan. Research on Financing Risk Management of Multinational Corporations [D]. Shandong University, 2006.

[7] Dong Yueshuang. Research on Financing Problems of Multinational Corporations in China [D]. Northeast Forestry University, 2005. 